\title{
INSTITUTIONAL ASPECTS OF SOLID WASTE TREATMENT IN RUSSIA
}

\author{
Vadim Chekalin \\ Elena Tarasenko \\ Vadimir Zakrzhevsky \\ St. Petersburg State University of Engineering and Economics, Russia
}

\begin{abstract}
Now reduced share of industrial waste in comparison with the 80s is obvious in Russia. Simultaneously, share of municipal waste increases. A rather high part of industrial waste is used for recycling, but in the same time recycling for municipal waste is seldom. A few wastes are used for energy production. It concerns both municipal and wooden waste. The only one exception is pulp and paper mills. The most part of municipal waste is disposed in landfills and dumps including illegal ones. Waste treatment plants including incineration ones are only in several big cities (Moscow, St Petersburg, Samara). These plants are based on rather old technologies, as a rule. The main reason of such situation is absence at national and regional levels of a necessary legislation base that stimulates more effective waste treatment in Russia. In particularly, there is no a well-developed policy in renewable energy resources. Too low prices for gas are also prevention for introducing waste in energy production. Administrative decisions without economic measures are the most common method of management. It needs to use methods of project management in this sphere. There is a serious problem of absence of qualified experts. Thus it is necessary educational and training programs that include all topics of solid waste treatment. For this purpose it should be better to cooperate with the EU countries. It will give possibility to use European experience for Russia. Besides it can give possibility to use Russian technological inventions for other countries. It needs to develop a legislative initiative for separate collection of waste. Legislation that should stimulate private business activity in solid waste treatment is necessary also. It is desirably to make correction of Russian rules in waste treatment for more harmonization with rules of the EU.

Now the amount and a variety of solid wastes in Russian cities and settlements is promptly growing.

In spite of the fact that the amount of industrial waste in comparison with the 80's has considerably decreased, there is an appreciable increase of the amount of municipal waste. It is necessary to mean, that the significant part of industrial waste is exposed to processing, first recycling (metals, pulp-and-paper production, glass, plastics). In the same time recycling for municipal waste is developed rather poor.

This situation is caused by several factors:
\end{abstract}


KALMAR ECO-TECH'03

Bioremediation and Leachate Treatment

KALMAR, SWEDEN, November 25-27, 2003

After the beginning of market reforms in Russia the sector of trade in which modern methods of good packing began to develop very fast. It has resulted in the sharp increase of wastes, containing paper, plastic, cardboard, and glass.

In the Soviet period circulation of glass packing (bottles, cans) was rather good due to a well-developed enough infrastructure and used methods of economic incentives for circulation (first on the base of a high mortgaging price). Thus the significant part of retumed packing intended for a reuse. For example, glass bottles for milk were used on the average 9 - 10 times.

Measures of incentives for the population for recycling pulp-and-paper production were also developed. Collecting food waste for use as additives in forage to cattle was carried out.

However last years big reducing of glass share and growth of plastic packing one happened changes. Packing in aluminum cans has appeared.

Meanwhile, however, as a rule, glass receptacle did not be used repeatedly, and its collecting as a base for manufacture of new receptacle economically does not be stimulated. At the same time there is a certain interest to collecting aluminum cans that is connected to rather high prices for an aluminum waste. Unfortunately, because of backwardness of the infrastructure for collecting metal waste in the municipal sector a process of this collecting is sometimes rather criminal. Besides collectors is mostly the poorest part of the population.

Simultaneously the amount of home electronic and electric devices (computers, communication devices, household devices: refrigerators, TVs, radio sets, audio and video recorders and types) increases considerably with improvement of well-being of the population.

Stable growth of the number of cars is observed.

Revival of the construction industry promotes expansion of the list of used materials. Thus practice of application of rather dangerous materials (asbestos, PVC) is kept unfortunately.

Food reduces are not allocated in the separate group now at collecting though use of old Soviet principles would allow to collect organic waste products for composting. These are 30-40 percents from all weight of waste, thus it would be possible to receive the ground for use in a garden facilities and in landscape gardening construction

Collecting and transportation of solid waste products Russia

By the present moment a basic scheme of collecting and transportation of solid waste did not change, except the increase of a number of the non-authorized dumps. City dwellers collect household waste within the limits of their apartments in waste cans, dust from which then is moved to municipal containers, which are located in courtyards. Many houses are equipped with refuse chutes from which solid waste also is got to municipal containers located in special spaces in the ground floor. Special machines come under certain schedules to transport the filled waste containers to special polygons (landfills) or incineration plants. The locations of municipal containers and clearing units of refuse chutes are mostly in unsatisfactory sanitary conditions, being a source of numerous rats and cockroaches.

Offices of firms and administrative establishments have contracts with specialized transport agencies for transportation of solid waste. The vehicles belonging to specialized motor-vehicle pools, as a rule, are equipped with hydraulic elevating adaptations to lift 
KALMAR ECO-TECH'03

Bioremediation and Leachate Treatment

KALMAR, SWEDEN, November 25-27, 2003

municipal containers. However they are not completed with the equipment of dust densification in containers. The collected waste is overloaded to big volume containers in the overload points and then is transported by special transport to places of landfilling or processing.

Vehicles of the specialized motor-vehicle pools are worn strongly out, as the majority of them were acquired in 1980th years. Probably, soon they will require repair or even to replacement.

The account of transported dust is made according to volume of containers, instead of weight of contents that conducts to overestimate costs of the companies - carriers.

Separate collecting of waste in initial stage of collecting remains while only at a level of projects and experiments. Thus, non-selected solid waste is delivered to places of landfilling or processing. Really, partial separating of collected waste is made directly in processing plants. For this purpose a special conveyor is used where workers take off some sorts of waste materials for further recycling.

\section{PROCESSING OF SOLID WASTE}

In Russia, in general, modern methods of processing and recycling of solid waste are known. Thus both domestic technologies are developed and foreign experience is used to some extent.

There is a very small share of waste is used for energy production. It concerns both household waste and bio-waste from forestry and wood processing industries. Bio-waste from pulp-and-paper industry is only one exception: this waste is mostly used for energy production for own needs of enterprises. The most part of municipal waste is taken out to landfills and dumps, enough frequently illegal. There is only several waste processing enterprises, including incineration plants (Moscow, St Petersburg, Samara). Unfortunately these enterprises are based, as a rule, on rather old technologies.

Decontamination of solid waste as one of elements in the system of cleaning of the occupied places is the most important as that is at this stage solid waste should become a harmless substratum in the epidemiological and sanitary attitudes.

At the formation and development of cities there were two basic methods of decontamination of solid waste: utilization (processing of waste into organic fertilizers or bio-fuel, allocation of secondary raw material for the industry, use of non-utilized combustible parts as fuel) and liquidation (landfilling, dump into the sea, and buming without use of heat).

From the technological essence methods of decontamination can be divided into:

1) Bio-thermal (dumps, landfills, polygons, compost fields and bio-thermal composting plants);

2) Thermal (burning without use of resulted heat, burming with energy production, pyrolysis with reception of combustible gas and oils);

3) Chemical (hydrolysis);

4) Mechanical (separation of waste with the subsequent recycling, densification of waste in construction blocks).

Bio-thermal methods of decontamination of solid waste satisfying to the hygienic requirements are the most used now: decontamination in bio-thermal chambers, composts and trenches, a bookmark in the hotbeds, advanced dumps, the accelerated industrial ways of bio-thermal decontamination of dust. 
KALMAR ECO-TECH'03

Bioremediation and Leachate Treatment

KALMAR, SWEDEN, November 25-27, 2003

Unfortunately, compost quality in Saint Petersburg, as a rule, is unsatisfactory as origin solid waste is contaminated to a big content by heavy metals, including zinc, copper, cadmium and etc. It results mainly from electric battery cells. For this reason public health services forbid to use such compost for the agricultural purposes. Besides as a result of absence of separate collecting of waste compost contents also glass and other undesirable components, including, poisonous salts. Finally the end product turns out poor-quality and unsuitable for the further use.

A problem of municipal waste is not solved by a choice of technology as besides technological aspects it has economic, social and organizational ones, which should be considered in a single complex.

\section{FINANCING OF WASTE TREATMENT PROCESSES}

The basic source of financing is payment of the population which is carried out according to federal specifications and which do not stimulate neither the population, nor business for normal operating of waste treatment processes.

For example, tariffs for utility services in St Petersburg are calculated on the basis of the Method of planning, accounting and calculation of cost of housing and communal services, authorized by the decision of State Committee of Construction and Living Housing of Russian Federation in 1999 and carrying obligatory for all subjects of the Russian Federation character. According to this document treatment of solid waste should include transportation and processing.

The most part of financing settles in the waste transportation organizations. The organizations connected to waste collecting and processing have small financing.

Transportation is only one profitable element of a "waste" chain (including also illegal incomes). Transportation companies create serious problems for processing enterprises frequently because they bring more dust to processing enterprises, than are declared in related documents. The reason of this is that carriers take containers from municipal housing services and then by the way to the plant add some illegal waste. Payment for this additional waste is provided in cash directly a pocket of a driver. Such shadow business is possible because waste in containers is not densified initially. As a result municipal housing services receive money in dependence of total number of transported containers with taking into account only volume of waste but not weight. Owners of the illegal waste, as a rule, different companies: shops, cafes, restaurants and etc. Under the law they should pay for transportation of waste, its processing, and also a tax for waste environmental impact. In the case of illegal transportation they save own money. In general, the committee on environment of St. Petersburg City Administration should keep up the correctness of payment of the environmental tax, but it works poorly.

There are numerous places in Russia where in general there is no practice of the centralized management system for solid waste treatment.

Besides there is no municipal police service in Russia that should keep up also conditions of solid waste treatment. The militia in a present kind has no necessary staff for such activity. Besides penalties are not too big, and the procedure of their application is complicated. As a result the system of impunity is created.

In some cases there is no control in general for illegal contamination of territories. For example, such a situation exists along all railways of Russia, as jurisdiction of municipalities is not distributed to territory along railways at all. 
For this reason there are a huge number of illegal dumps giving enormous threat to the environment.

At the same time it is necessary to note, that the sphere of solid waste transportation is the most competitive, and consequently in private companies try to come in it.

Organic waste is not really used for fuel and energy production (except bio-fuel from pulp-and-paper industry where there is benefit for manufacturers to use their own waste).

Practically there is no a well developed policy for renewed energy resources. Very low prices for gas interfere with use of waste for energy production. Administrative decisions without economic measures are the most widespread methods of management. It is necessary in this sphere to use appropriate methods of project-management.

\section{LEGISLATION SYSTEM IN SOLID WASTE TREATMENT}

The main reason of the current situation in solid waste management in Russia is the absence of adequate legislative system at the levels of the country and regions, which could stimulate more effective solid waste treatment.

A series of laws and acts in the sphere of solid waste treatment was accepted last years in Russia. The federal program "Waste" is under the operation. At the same time the existing legislative base does not take into account economic and psychological aspects, does not create a motivation for the population and business-community. The legislative base of Russia in this sphere lags considerably behind specifications in this area, accepted by the European Union. For example, within the framework of the measures determined by the Concept of St Petersburg for solid waste treatment, there is a plan to construct a new incineration plant with use of technology, which falls since January 2001 under the prohibition by instructions of The European Union.

In the sphere of solid waste treatment St Petersburg Administration and Government of The Leningrad region (oblast') are guided by federal and regional laws and decisions. However the legislation of the Russian Federation in the nature protection basically has a superficial character and particularly does not allow to solve many problems, for example, to carry out the strict control for waste movement. So, according to the law of the Russian Federation, «On waste products of manufacture and consumption», accepted in 1998, the responsibility for the non-authorized dump of waste is specified, but effective mechanisms of realization of this item are absent till now. The law of the Russian Federation "On preservation of the environment», accepted in 2001 establishes payment principles for solid waste accommodations. However and today there are no under-law acts determining procedure of the control over formation, movement and decontamination of waste that complicates the realization of requirements of the Law.

Thus, it is necessary to ascertain the absence of many necessary legislative acts at the federal level that complicates conducting in regions of appropriate account of solid waste formation and the control over its movements up to the final stage of processing. It gives negative impact for opportunities to take payment for accommodation and processing of waste.

By the federal law "On waste products of manufacture and consumption» it is determined, that subjects of the Russian Federation provide the realization of the state policy in the field of solid waste treatment in their territories. Own responsibilities of these subjects in the field of solid waste treatment are limited to the following topics: 
KALMAR ECO-TECH'03

Bioremediation and Leachate Treatment

KALMAR, SWEDEN, November 25-27, 2003

- Planning and construction of objects of landfilling, processing and decontamination of solid waste;

- Development and realization of regional target programs in the sphere of solid waste treatment;

- Maintenance of economic, social and legal conditions for minimization of the amount of solid waste and its more full use as secondary raw material.

Thus, the regional environmental policy regarding solid waste treatment should meet to the nation-wide policy and reflect at the same time territorial features of the region, in particular a degree of anthropogenic impact on its environment. Existence of special regional standards, sanitary or building rules and norms would result contradictions between federal and local laws, or useless recurrence of nation-wide requirements in local documents.

Therefore the regional legislative and executive authorities cannot let out the standards, sanitary and building rules and norms etc. Regional requirements regarding solid waste treatment are expressed in orders of the executive authorities regulating the given kind of nature protection activity.

For maintenance of normal operating the system of solid waste treatment the formation of sustainable and universal legislative base at all levels is necessary

\section{EDUCATION AND TRAINING}

Availability of the appropriate personnel is a very serious problem for the sphere of solid waste treatment. There are no really complex education programs in Russia for this sphere; now there are only separate courses and programs on ecology, wildlife management, sanitary clearing the cities. These programs cover single divisions of this sphere, but not the system as a whole.

As a result, the level of education and vocational training of the employees for this sphere is rather low. It is also resulted from a low level of wages in this sphere. Attraction of private Russian capital and, especially, foreign investments and getting the profitable work of the enterprises of this sphere would allow to increase wages of employees and to involve in this sphere more qualified personnel. Besides, realization of training programs and improvement of professional skill of employees are necessary.

Coming of a new generation of managers having fresh ideas, skills of administrative activity and an operational experience in the given sphere is the most actual. Training abroad both working and new managers is one of perspective directions for educational activity and improvement of professional skill of the staff.

Educational activity is important for all participants of the process of solid waste treatment: city dwellers, collectors of waste, staff of transport enterprises and enterprises for waste processing, representatives of local authorities responsible for this sphere.

Educational activity at the initial stage assumes psychological training of all participants of the process, attraction public attitude to the problems of solid waste management in the city and the country as a whole, acquaintance with high technologies in this sphere, providing conferences and seminars with the purpose of an establishment of mutually advantageous contacts inside the region and with other regions. For achievement of this 


\section{KALMAR ECO-TECH'03}

Bioremediation and Leachate Treatment

KALMAR, SWEDEN, November 25-27, 2003

purpose the greatest interest represents experience both of old countries of the European Union and new candidates. The last is seemed especially important whereas in many of them the system was completely similar present Russian.

Undoubtedly, experience of Nordic countries is very attractive as in these countries the share of use of solid waste for energy production is highest in Europe. It is especially important because energy production based on solid waste incineration in these countries is combined with a principle of district heating which is widely used also in Russia.

It is also very important to provide psychological training for population with including appropriate measures of PR. For example, for the organization of separate collecting solid waste in various containers it is necessary to provide psychological readiness of the population for such separation within the limits of each family. In a reality by the present moment such readiness is absent at the majority of the population.

\section{CONCLUSIONS}

The carried out analysis of a current situation in the sphere of solid waste treatment in big cities of Russia has shown, that there are many problems in this sphere. There is an imperative need of change of the usual practice.

This economic sector in Russia becomes effective only under providing some conditions: First, tariffs for processing should cover the most part of production expenses.

Second, it is necessary to change a system of payment in this sphere. Transport enterprise should receive money not for volume, but for weight. It will result excluding manipulations with the illegal cargo due to waste densification. Processing enterprises will receive money for processing from legal persons in full.

Thirdly, it is necessary to reconstruct processing enterprises and basic landfills and polygons.

Only after that it will be possible to develop profitable, investment attractive areas of processing. It, first of all, paper, rubber, plastic, worn out home appliances, landscapes gardening waste products. As soon as the source of the profit here will appear, private business will come/ It will mean that "the waste question" will start to be "self-regulated". However for such "self-regulation" the chain should work effectively. Each part of a "waste" chain should have benefit from the interrelation work with other participants of this market, within the framework of one business-circuit when one is interested in the success and qualitative work of another and by him promotes the success. A general coordinator is necessary for this purpose. Such a coordinator can be a single municipal body, which adjusts the whole way of solid waste from "a domestic bucket up to the resulted product".

To improve the efficiency of system operating, it is necessary to make measure for its perfection:

- Improvement of the legislation system.

- Active promotion of educational and training programs for all participants of the solid waste management system in the country.

- Wide use of international experience (including, in the legislation base).

- Creation of a transparent financial system in solid waste treatment. 
KALMAR ECO-TECH'03

Bioremediation and Leachate Treatment

KALMAR, SWEDEN, November 25-27, 2003

It is very promising is activity of a new Russian company «Russian Communal Systems», created by RAO UES, Gazprom and a number of other financial and industrial groups for the work in the sector of utility services, including, solid waste treatment. Actually, there is a first large private investor in this sector that can result in the nearest future essential increase of its efficiency.

It is important to note, that only use of a strategic integrated approach on the basis of a combination of several complementary programs and measures can promote the effective solving of solid waste problems in cities. 